\title{
New aspects of spondyloarthritis pathogenesis. Part III - arthritis, pathological bone remodeling
}

\author{
Nowe aspekty patogenezy spondyloartropatii zapalnych. \\ Część III - zapalenie stawów, patologiczna przebudowa kości
}

\author{
Ewa Kontny \\ Department of Pathophysiology, Immunology and Pathomorphology, Institute of Rheumatology, Warsaw, Poland
}

Key words: destruction processes, pathological bone remodeling, cytokines.

Słowa kluczowe: procesy destrukcyjne, patologiczna przebudowa kości, cytokiny.

\section{Sum mary}

Spondyloarthritis (SpA) is a form of chronic inflammatory arthritis affecting axial and peripheral joints, which may be initiated by inflammation of joint subchondral bone marrow or enthesitis. Invasive fibrous tissue which substitutes bone marrow, entheseal innate-like T lymphocytes and proinflammatory cytokines: tumor necrosis factor (TNF), interleukins 23, 17 and 22, all contribute to these local pathological processes. Joint inflammation, joint cartilage and bone destruction are mediated by mechanisms that are molecularly similar to rheumatoid arthritis. These pathologic processes are halted by effective anti-inflammatory therapy, including anti-TNF biological agents. By contrast, anti-TNF therapy fails to inhibit pathologic new bone formation, which is a unique hallmark of SpA and results, among others things, in syndesmophyte formation followed by spine ankylosis. The molecular mechanisms driving pathologic bone remodeling in SpA patients and interaction of this process with inflammatory pathways are not fully understood. Three hypotheses, discussed in the article, have been proposed to explain this issue.

\section{Introduction}

Spondyloarthritis (SpA) develops in various joints of the body including sacroiliac (sacroiliitis) and spinal (spondylitis) joints as well as paraspinal tissues and peripheral joints, especially in the lower limbs, where the pattern of affected joints is typically asymmetrical [1]. One manifestation, which helps differentiate SpA from other rheumatic inflammatory conditions is enthesitis - inflammation of the sites where tendons,

\section{Streszczenie}

Spondyloartropatie (SpA) są formą przetrwałego zapalenia stawów obwodowych i kręgosłupa, które może być zapoczątkowane przez zapalenie podchrzęstnego szpiku kostnego w stawach albo zapalenie przyczepów ścięgnistych. Inwazyjna tkanka włóknista zastępująca szpik kostny, rezydujące w przyczepach ścięgnistych limfocyty T o cechach komórek odporności wrodzonej oraz cytokiny: czynnik martwicy nowotworów (tumor necrosis factor - TNF), interleukiny 23, 17 i 22, biorą udział w tych lokalnych procesach patologicznych. Mechanizmy molekularne, które biorą udział w zapaleniu stawów, destrukcji chrząstki i kości stawowej, są podobne do tych w reumatoidalnym zapaleniu stawów i są zatrzymywane przez skuteczną terapię przeciwzapalną, w tym leki biologiczne neutralizujące TNF. Terapie anty-TNF jednak nie hamują patologicznego tworzenia kości, a to zjawisko jest cechą charakterystyczna SpA. Powoduje ono m.in. powstawanie syndesmofitów i ankylozę kręgosłupa. Mechanizmy molekularne leżące u podłoża patologicznej przebudowy kości w SpA, jak również ich interakcje ze szlakami zapalnymi nie są w pełni poznane. Trzy główne omówione w artykule hipotezy są próbą wyjaśnienia tego problemu.

ligaments, or joint capsules insert into bone [2]. Unlike in rheumatoid arthritis (RA), where inflammation is associated with focal bone erosion and diffuse osteoporosis with minimal bone regeneration, erosive bone damage in SpA is associated with pathological bone remodeling. This process manifests via bone spur (osteophyte) and bridge (syndesmophyte) formation. There is also ossification of entheses with enthesophyte formation.

Address for correspondence:

Prof. Ewa Kontny, MD, PhD, DSc, Department of Pathophysiology, Immunology and Pathomorphology, Institute of Rheumatology, Spartańska 1, 02-637 Warsaw, Poland, e-mail: ewa.kontny@wp.pl

Submitted: 30.04 .2014 
Patients with ankylosing spondylitis (AS) develop spinal stiffness, or ankyloses, as a result of pathological bone remodeling, which together with limb contractures due to peripheral joint involvement leads to severe disability [3]. Bone changes in the form of structural damage, such as in RA, involving peripheral joint destruction are typical mainly for psoriatic arthritis (PSA), and are less commonly found in other forms of SpA [4]. Nevertheless, erosive bone damage and pathological bone apposition may take place in the same joints, e.g. sacroiliac joints in AS or small joints of the hands in PSA. Common complications of AS are osteopenia, osteoporosis, and vertebral fractures, the latter often undiagnosed [5-7]. Low bone mineral density and osteoporosis can be detectable already within the first decade of the disease (in $51-54 \%$ and $13-16 \%$ of patients, respectively) [5]. Recent findings suggest a very early manifestation of a significant loss of bone mass in the lumbar segment of the spine in patients with axial SpA - as soon as in the first year of the disease [8].

The molecular mechanisms underlying destructive processes (cartilage degradation, bone resorption) in RA and AS are similar [9], and are associated with inflammation. Biological medications that neutralize the tumor necrosis factor (TNF) inhibit the inflammatory response, reduce the rate of bone destruction, and significantly increase bone mass [8-12]. The mechanisms responsible for pathological bone remodeling in AS are not fully understood. Moreover, there is no consensus as to whether this process is dependent on and/or associated with inflammatory response. This issue is currently under discussion (see below). Resolving this controversial issue is significant not only from an exploratory but also from a practical point of view, as it should facilitate the selection of a suitable therapeutic option.

\section{Where does arthritis begin?}

Patients with SpA develop synovitis, subchondral bone marrow inflammatory infiltrates, chondroid metaplasia, cartilage destruction, as well as calcifying tendinitis. Many reports suggest that, unlike in RA, synovitis in SpA is a secondary and not primary phenomenon. There have been reports suggesting that subchondral bone marrow and/or entheses are the primary sites affected by inflammation. From there, the inflammatory infiltrate spreads onto the synovial membrane.

\section{Inflammatory infiltrates in the joints}

Previous studies evaluating peripheral joint abnormalities revealed that in patients with SpA as well as in those with RA cells belonging to both the innate (neutrophils, macrophages, mast cells, and dendritic cells) and adaptive ( $T$ cells and B cells) immune systems accu- mulate in the synovial membrane. However, significant quantitative differences were observed: namely synovial vascularization, neutrophil count, and the so-called alternatively activated macrophages (CD163 ${ }^{+}$) involved in reparatory processes were higher in SpA, whereas synovial lining hyperplasia and T cell count, with predominantly cytotoxic T cells $\left(\mathrm{CD}^{+}\right)$were lower than in RA [13]. Similar differences were observed in peripheral joints of patients with PsA. These patients also demonstrated memory $T$ cells that migrated from the skin to joints, and ectopic lymphoid aggregates, including $T$ cells and $B$ cells, that formed in the synovial membrane; however, unlike in RA, no local antibody synthesis was detected [14].

Cellular infiltrates found in sacroiliac joints of patients with early and active form of SpA are located both in the synovial membrane and in subchondral bone marrow, and are composed mainly of T CD4+ cells, $\mathrm{CD}^{+}$cells and macrophages. What is also characteristic is hypervascularization and high resorptive activity of osteoclasts, which form aggregates in subchondral bone marrow $[15,16]$. In the late phase of disease, with complete destruction of joint cartilage, the number of infiltrating cells becomes smaller, the bone marrow undergoes fibrosis, and a number of bone-forming cells (osteoblasts) create a dense layer surrounding trabecular bone, which indicates an ongoing remodeling process [16]. These findings suggest that inflammation in SpA begins in the subchondral bone marrow, and it may be caused by antigens released from the damage cartilage.

\section{Enthesitis}

A comparative anatomical study, histopathological analysis, and imaging studies conducted several years ago, yielded a supposition that entheses may also be the primary site of musculoskeletal inflammation in SpA $[2,8,17,18]$. Studies with magnetic resonance imaging (MRI) helped to identify 2 types of arthritis: 1 ) associated with RA, with the first pathological manifestation in the form of synovitis, 2) associated with SpA, with primary development of enthesitis, often associated with bone edema indicating osteitis, and synovitis developing later. Nonetheless, we would like to emphasize that more recent reports have indicated that peripheral arthritis in treatment-naïve patients with early SpA is not specifically associated with enthesitis, as incidence rates of enthesitis and synovitis are similar to those in RA [19].

Entheses are composed of fibers forming tendons/ ligaments, uncalcified fibrocartilage, and mineralized fibrocartilage directly adjacent to bone. These, together with adjacent tissues form a functionally distinct "organ" that transfers and distributes forces generated by muscle onto the bone. The fibrocartilage provides a certain degree of stiffness and ensures better distribution 
of the mechanical strain between soft and hard tissues, whereas the tendons/ligaments smoothly glide over the surface of the bone [18]. Entheses are constantly exposed to mechanical strain, which results in microinjuries. Due to the proximity of fibrocartilage of periarticular entheses to the synovial membrane microinjuries were believed to possibly induce local inflammatory response spreading onto the synovial membrane. However, this has been difficult to prove due to limited accessibility of tissues from SpA patients. Supportive evidence was provided by recent studies in animals with the disease induced experimentally via introduction of the interleukin 23 encoding gene (tgIL-23 mice) [20]. One important finding in these mice was identification of atypical entheseal resident $T$ cells $\left(\mathrm{CD}^{+}{ }^{+} \mathrm{CD} 4^{-} \mathrm{CD} 8^{-} \mathrm{ROR}-\gamma \mathrm{t}^{+} \mathrm{IL}-23 \mathrm{R}^{+}\right)$. Induced by IL-23, these cells were shown to produce other cytokines (IL-17, IL-22) and those cytokines were shown to mediate the initiation of enthesitis and local bone remodeling. Entheseal resident $T$ cells resemble cells of the innate immune system - as they are ready to launch an immediate inflammatory response and bone regeneration at an anatomical site particularly prone to microinjuries. In this SpA model, a later stage of the disease sees macrophages and neutrophils infiltrating entheses. Inflammation also involves the synovial membrane of joints, and anabolic processes take place concomitantly with catabolic ones (cortical bone erosion by osteoclasts, joint surface destruction).

\section{Cytokine involvement in arthritis}

Involvement of cytokines in joint inflammation in patients with SpA is supported by increased in situ expression of cytokines, effectiveness of therapies neutralizing selected cytokines, and animal studies. The expression of pro-inflammatory cytokines, especially TNF, in peripheral joints of patients with SpA is similar to, or lower than, that in RA [13]. Peripheral and sacroiliac joints also exhibit IL-17 expression [21, 22]. Synovial fluid in patients with SpA shows elevated concentration of IL-23 [23]. High expression of this cytokine has also been found in vertebral facet joints, where the cytokine is produced by macrophages residing in fibrous tissue and neutrophils, macrophages, and dendritic cells found in subchondral bone marrow [24].

TNF-neutralizing biologics cause a rapid reduction of inflammation in patients with axial and peripheral SpA, and reduce synovial membrane vascularization and its infiltration by neutrophils, macrophages, and $T$ cells. These medications also inhibit joint destruction, while they do not stop abnormal bone formation in axial SpA or peripheral PSA, and the disease typically relapses after treatment is discontinued $[25,26]$. TNF occurs in its soluble (sTNF) and transmembrane (tmTNF) form. The extent to which these TNF forms play a role in SpA pathogenesis in humans is currently unknown. Animal studies indicate that it is varied [27]. In mice with the disease induced by introducing a human gene encoding TNF while simultaneously blocking an osteoblastogenesis inhibitor (Dickkopf-1 protein - DKK-1), sTNF induces a generalized, debilitating inflammatory response with peripheral and sacroiliac arthritis, whereas transgenic mice with introduced tmTNF do not develop systemic inflammation but pathological bone remodeling in axial and peripheral joints which leads to ankylosis. In this model, tmTNF acts locally resulting in synovitis, osteitis, and spondylitis. The molecular mechanism responsible for these tmTNF effects is still unknown.

A number of observations indicate that IL-23 and the cytokines it induces (IL-17, IL-22) play a key role in SpA pathogenesis. A systemic increase in IL-23 expression in tgIL-23 mice induces a disease of typical SpA symptoms: axial and peripheral joint enthesitis, bone remodeling at the site of these entheses, and aortic inflammation [20]. In this SpA model, IL-22 plays a more important role than IL-17, as it is responsible for bone renewal by inducing its regulatory genes, e.g. genes encoding Wnt-family proteins and bone morphogenic proteins (BMP). Patients with SpA typically exhibit elevated IL-23 at the affected sites, in the gut and joints, although there are also reports of elevated serum IL-23 levels [23, 27, 28]. Interleukin 23 maintains a pool of Th17 cells in the body, as it stimulates these cells to proliferate. The Th17 cell count in peripheral blood of AS patients is often elevated, but so is the proportion of other IL-17-producing cells: $T \gamma / \delta$ IL-23R(+) and Th17KIR3DL2(+) cells $[29,30]$. The proportion of IL-22-producing Th22 cells in peripheral blood is also elevated, but it does not correlate with disease activity [31]. Contrary to their peripheral blood counts, the number of Th17 cells in the affected peripheral and vertebral facet joints is negligible, with innate immunity system cells (neutrophils, mast cells, $T \gamma / \delta$ lymphocytes) being the source of IL-17 [21, 22]. These findings suggest that IL-23, IL-22, and IL-17 take part mainly in local pathogenic processes in SpA. Little is known about the effects of these cytokines on affected tissues in patients with SpA. Animal studies indicate a contribution of IL-17 and IL-22 to arthritis [20, 27]. However, these cytokines play a protective role in the gut [32]. An IL-23/IL-12-neutralizing medication (ustekinumab - an anti-IL-12/23 p40 monoclonal antibody) was shown to be highly effective in psoriasis and PsA, with ongoing clinical studies on AS. Similarly, the IL-17-neutralizing biological drugs have good therapeutic effects in psoriasis, and clinical studies indicate efficacy of the anti-IL-17A antibody, secukinum$a b$ in AS and PsA [27]. 


\section{Pathological bone remodeling in spondyloarthritis}

The bone that forms the articular surface includes a subchondral osseous plate composed of compact cortical bone and deeper trabecular bone encased within bone marrow. The bone forming the joint margins and extending distally beyond the joint is compact and covered with a periosteal layer. Biological and biomechanical signals derived from the articular environment cause significant changes in periarticular bone at all of these sites [9]. These changes take place via bone remodeling, which involves three types of cells: bone-forming osteoblasts of mesenchymal origin stem cells, osteoclasts derived from a myeloid lineage, and osteocytes that regulate this process. Bone remodeling begins with the osteoclast-driven resorption phase, followed by bone formation by osteoblasts, which produce bone matrix and cause its mineralization. Bone formation may occur in two ways: either directly, with mesenchymal stem cells (MSCs) immediately differentiating into osteoblasts, or via endochondral ossification, with MSCs first differentiating into chondrocytes, forming a cartilage scaffold, and then dying via apoptosis, while subsequent MSCs residing in this scaffold differentiate into osteoblasts [33].

In normal conditions, bone resorption and formation are quantitatively balanced and precisely regulated by various factors. These factors include: receptor activator of NFKB ligand (RANKL), which is essential for osteoclast formation and activation of their bone resorptive activity, growth factors that stimulate bone formation [e.g. transforming growth factor $\beta$ (TGF $\beta$ ), BMP, parathormone, insulin-like growth factor] and endogenous proteins (sclerostin, DKK-1, noggin) that inhibit the signaling pathways regulating osteoblast formation from MSCs. Osteocytes, the most prevalent bone cells, derived from mature osteoblasts, are situated deep within the bone matrix, and form a network of cells, communicating with one another and with cells on the bone surface. Due to the factors produced (such as RANKL and sclerostin) osteocytes regulate physiological bone remodeling $[9,34]$.

Spondyloarthritis involves a disruption of the balance between bone resorption and formation, which leads to pathological bone remodeling. The expression of proteins associated with bone homeostasis indicates that the affected joints undergo bone formation - in sacroiliac joints, TGF $\beta$ is expressed near the sites of new bone tissue formation, and osteocytes almost completely lack sclerostin $[35,36]$. Similarly, synovial fibroblasts and macrophages of peripheral joints demonstrate high expression of bone morphogenic proteins (BMP-2 and BMP-6) [37]. Interestingly, resorption and rebuilding of bone may develop independently, as in SpA patients with
Achilles tendonitis local bone loss and excessive bone formation occur in different sites - exposed to compression forces or to mechanical strains, respectively [38].

Recent studies have provided information on the sequence of events occurring during pathological bone remodeling in vertebral facet joints in patients with AS [39]. Based on histomorphological and histomorphometric assessments conducted in patients undergoing corrective spinal surgery, three groups of joints with various abnormalities have been identified: 1) joints with a preserved articular space, 2) with partial cartilaginous fusion of articular surfaces, and 3) complete osseous fusion. Groups I to III showed progressive reduction of articular cartilage and subchondral bone plate thickness. In groups I and II reduction of cartilage thickness was caused by chondrocyte apoptosis, while group III, with only remnant cartilage "islands", showed proteoglycan loss, which indicates defective cartilage matrix production by chondrocytes and/or its progressive ossification or mineralization. All of these phenomena indicate progressive degeneration of articular cartilage. At the same time, group II and III joints demonstrated formation of fibrous tissue which replaces subchondral bone marrow. Importantly, in groups I and II fibrous tissue penetrated into the joint, invaded the subchondral bone plate and reached articular cartilage. This invasive fibrous tissue resembled rheumatoid pannus and was responsible for erosion of the subchondral bone plate. These findings support the view that arthritis in AS begins with subchondral bone marrow inflammation $[15,16]$. They also suggest that the invasive bone marrow-derived fibrous tissue not only causes erosion of the subchondral bone plate but may also provide MSCs capable of differentiating into osteoblasts or chondrocytes, which initiates ossification via the direct or endochondral route.

Studies in vitro and animal studies have provided information explaining the molecular mechanisms involved in pathological bone remodeling in SpA [33, 40, 41]. These studies demonstrated that bone defects are first filled with fibrous tissue, and later the bone is rebuilt, typically via endochondral ossification, but sometimes directly. In the case of entheses, ossification progresses towards the damaged insertion site, with new fibrous tissue forming above it. At the molecular level, bone remodeling occurs via 2 pathways: a BMP-dependent pathway, which functions in an early phase of the process when progenitor cells undergo chondrogenesis and form a cartilaginous scaffold, as well as a Wnt-dependent pathway, which is initiated later, during endochondral ossification. Both of these pathways are regulated by physiological protein inhibitors: noggin (a BMP inhibitor), DKK-1 (a Wnt inhibitor), and sclerostin (an inhibitor of both pathways). BMP expression is induced 
by pro-inflammatory cytokines (TNF, IL-1, IL-22). The effects of cytokines on the Wnt-dependent pathway are complex, as TNF exhibits its inhibitory effect (increasing production of inhibitors of this pathway), whereas IL-22 exhibits an activating effect. Mechanical loading is also responsible for bone formation, as it stimulates osteocytes to produce BMPs, activates the Wnt pathway, and inhibits the production of DKK-1 and sclerostin [42, 43]. Also in vivo, a murine SpA model shows that mechanical strains cause enthesitis and bone remodeling, and these processes involve stromal cells [44].

Growing on vertebral bodies, syndesmophytes form bone bridges and result in vertebral stiffness (ankylosis), which is the main cause of disability in SpA patients. Thus, a number of clinical observations are being conducted aiming to identify predictive factors, to assess syndesmophyte formation dynamics and the effects of therapy on progression of these structural abnormalities. To date, there has not been a clear opinion on this issue. Some observations indicate that syndesmophytes form when advanced inflammatory lesions assessed via MRI are replaced by adipose tissue - this sequence of phenomena occurs in corners of the vertebrae, which correspond to the location of entheses [45]. Other authors indicated that after a 5-year follow-up, most $(57.4 \%)$ of new syndesmophytes are formed on the edge of vertebral bodies, with no previous pathological lesions [46]. Nevertheless, these authors also confirm that the highest risk of developing syndesmophytes after 5 years resulted from simultaneous presence of inflammatory lesions and fatty degeneration at the beginning of the follow-up period [relative risk $(R R)=3.3$ ], with adipose abnormalities alone posing a lower risk $(R R=2.3)$, and the inflammatory lesions alone had very limited predictive value $(R R=0.8)$, and most of them $(>70 \%)$ resolved with time. These assessment differences may be due to a number of reasons, including various demographic and clinical characteristics of the study group and treatment differences. Despite these discrepancies, most authors agree that syndesmophytes may form at any stage of the disease, and several markers, e.g. the presence of syndesmophytes at disease onset, male gender, elevated ESR value, elevated serum concentration of C-reactive protein (CRP) and low serum levels of bone formation inhibitors (DKK-1, sclerostin), are considered to be predictors of radiographic progression [36, 47-49].

\section{Hypotheses on the associations between an inflammatory response and pathological bone remodeling}

Along with the progress of studies on SpA pathogenesis, various hypotheses on the link between the inflam- matory process and pathological bone remodeling have been suggested. Understanding these relationships is important when making therapeutic decisions. Three main and noteworthy hypotheses have been presented below.

The "TNF brake" hypothesis is based on biological properties of TNF. This cytokine affects bone tissue in two different ways. On the one hand, it sustains bone inflammation and destruction, while on the other hand, it increases the production of an osteoblastogenesis inhibitor (DKK-1), which also inhibits bone formation. According to this hypothesis, the inflammatory response found in SpA patients resolves in time, which results in lower DKK-1 production and "unblocks" reparative bone formation. Therefore, inhibition of the TNF-mediated inflammatory response may have side effects - by enhancing pathological bone remodeling [50-52]. This hypothesis is supported by the fact that in patients with AS, bone formation is inversely correlated with the levels of DKK-1 and sclerostin [36, 49]. However, long-term follow-up studies of patients with AS receiving biological TNF-neutralizing agents, indicate that this therapy does not increase syndesmophyte formation, and may even slow it down somewhat, which contradicts the "TNF brake" hypothesis [53-56].

The entheseal stress hypothesis posits that the disease-inducing factor (e.g. cell stress, mechanical strains, infections) at the site of tendon/ligament insertion into bones results in simultaneous inflammation and pathological bone rebuilding $[17,18,20,33,44]$. Bone formation is possible due to osteogenic pathway activation in MSCs. Once initiated, both processes become independent from each other, which has been supported by some animal studies $[33,57]$. According to this hypothesis, therapeutic inhibition of an inflammatory response, even at an early stage of the disease would have no effect on bone rebuilding. One limitation of this hypothesis is the fact that it fails to explain why both local and systemic inflammation in patients with SpA is associated with progressive syndesmophyte formation [45, 48].

A recently proposed hypothesis posits that pathological bone formation in SPA is independent of STNF-mediated inflammatory response, but depends on pathways involving other pro-inflammatory factors and cytokines [27]. These may include IL-1, which stimulates MSC differentiation into osteoblasts, IL-22 and tmTNF, which cause osteoproliferation in animal SpA models, and prostaglandin $E_{2}\left(P G E_{2}\right)$, which has an anabolic effect on the bone tissue. Potential $\mathrm{PGE}_{2}$ involvement is also supported by SpA findings which indicate that pathological bone formation is inhibited by long-term blocking of prostaglandin synthesis with non-steroidal anti-inflammatory drugs (NSAIDs) [58]. The fact that this therapeu- 
tic effect is more pronounced in patients with high CRP levels additionally supports the belief that bone rebuilding can be initiated by sTNF-independent inflammatory pathways [59].

\section{Conclusions}

The musculoskeletal involvement in SpA may begin with enthesitis or subchondral bone marrow inflammation in joints. There are reports suggesting that invasive fibrous tissue replacing the bone marrow penetrates into the joint, causing subchondral bone plate damage, cartilage degradation, and synovitis, and may also provide precursor cells initiating pathological bone remodeling. Entheseal resident and IL-23-sensitive T cells may also initiate a local inflammatory response and bone remodeling, by producing cytokines (IL-22, IL-17). In SpA, STNF is responsible for the systemic inflammation response - and its neutralization results in clinical improvement, but does not inhibit pathological bone formation. Syndesmophyte formation may depend on pro-inflammatory factors other than sTNF, such as IL-1, IL-22, tmTNF, $\mathrm{PGE}_{2}$. To date, only chronic use of NSAIDs has been shown to limit this process in patients with SpA, which emphasizes the role of $\mathrm{PGE}_{2}$. A better understanding of the effects of these and other factors on pathological bone rebuilding should be the basis for developing novel therapeutic options for SpA patients.

The author declares no conflict of interest.

\section{References}

1. Zimmermann-Górska I. Wspólne cechy zapalnych chorób stawów z zajęciem stawów kręgosłupa. In: Reumatologia kliniczna. Zimmermann-Górska I (ed.). Wydawnictwo Lekarskie PZWL, Warszawa 2008; 729-731.

2. McGonagle D, Gibbon W, Emery P. Classification of inflammatory arthritis by enthesitis. Lancet 1998; 352: 1137-1140.

3. Zimmermann-Górska I. Zesztywniające zapalenie stawów kręgosłupa. In: Reumatologia kliniczna. Zimmermann-Górska I (ed.). Wydawnictwo Lekarskie PZWL, Warszawa 2008; 732-740.

4. Mease PJ. Psoriatic arthritis: update on pathophysiology, assessment and management. Ann Rheum Dis 2011; 70: i77-84.

5. van der Weijden MAC, Claushuis TAM, Nazari T, et al. High prevalence of low bone mineral density in patients within 10 years of onset of ankylosing spondylitis: a systematic review. Clin Rheumatol 2012; 31: 1529-1535.

6. Klinberg E, Lorentzon M, Mellström D, et al. Osteoporosis in ankylosing spondylitis - prevalence, risk factors and methods of assessment. Arthritis Res Ther 2012; 14: R108.

7. Klinberg E, Geijer M, Göthlin J, et al. Vertebral fractures in ankylosing spondylitis are associated with lower bone mineral density in both central and peripheral skeleton. J Rheumatol 2012; 39: 1987-1995.
8. Akgöl G, Kamanlı A, Ozgocmen S. Evidence for inflammationinduced bone loss in non-radiographic axial spondyloarthritis. Rheumatology (Oxford) 2014; 53: 497-501.

9. Goldring SR. Osteoimmunology and bone homeostasis: relevance to spondyloarthritis. Curr Rheumatol Rep 2013; 15: 342.

10. Braun J, Baraliakos X, Heldmann F, et al. Tumor necrosis factor alpha antagonists in the treatment of axial spondyloarthritis. Expert Opin Investig Drugs 2014; 23: 647-659.

11. Wendling D, Claudepierre P. New bone formation in axial spondyloarthritis. Joint Bone Spine 2013; 80: 454-458.

12. Machado P. Anti-tumour necrosis factor and new bone formation in ankylosing spondylitis: the controversy continues. Arthritis Rheum 2013; 65: 2537-2540.

13. Chou Ch-T. Why is biological therapy useful in spondyloarthritis? Knowledge from synovial immunopathological studies of spondyloarthritis. Int J Rheum Dis 2012; 15: 507-511.

14. van Kuijk AW, Tak PP. Synovitis in psoriatic arthritis: immunohistochemistry, comparisons with rheumatoid arthritis, and effects of therapy. Curr Rheumatol Rep 2011; 13: 353-359.

15. Bollow M, Fischer T, Reisshauer $\mathrm{H}$, et al. Quantitative analyses of sacroiliac biopsies in spondyloarthropathies: $T$ cell and macrophages predominate in early and active sacroiliitis - cellularity correlates with the degree of enhancement detected by magnetic resonance imaging. Ann Rheum Dis 2000; 59: 135-140.

16. Appel H, Kuhne M, Spiekermann S, et al. Immunohistochemical analysis of hip arthritis in ankylosing spondylitis. Evaluation of the bone-cartilage interface and subchondral bone marrow. Arthritis Rheum 2006; 54: 1805-1813.

17. Benjamin M, McGonagle D. The enthesistis organ concept and its relevance to the spondyloarthropathies. Adv Exp Med Biol 2009; 649: 57-70.

18. Yasser R, Yasser E, Hanan D, et al. Enthesitis in seronegative spondyloarthropathies with special attention to the knee joint by MRI: a step forward toward understanding disease pathology. Clin Rheumatol 2011; 30: 313-322.

19. Paramarta JE, van der Leij C, Gofita I, et al. Peripheral joint inflammation in early onset spondyloarthritis is not specifically related to enthesitis. Ann Rheum Dis 2014; 73: 735-740.

20. Sherlock JP, Joyce-Shaikh B, Turner SP, et al. IL-23 induces spondyloarthropaty by acting on ROR- $\gamma \mathrm{t}+\mathrm{CD} 3+\mathrm{CD} 4-\mathrm{CD} 8$ - enthesal resident T cells. Nature Med 2012; 18: 1069-1076.

21. Noordenbos T, Yeremenko N, Gofita I, et al. Interleukin-17-positive mast cells contribute to synovial inflammation in spondyloarthritis. Arthritis Rheum 2012; 64: 99-109.

22. Appel H, Maier R, Wu P, et al. Analysis of IL-17(+) cells in facet joints of patients with spondyloarthritis suggests that the innate immune pathway might be of greater relevence than the Th17-mediated adaptive immune response. Arthritis Res Ther 2011; 13: R95.

23. Romero-Sanchez C, Jaimes DA, Londoño J, et al. Association between Th-17 cytokine profile and clinical features in patients with spondyloarthritis. Clin Exp Rheumatol 2011; 29: 828-834.

24. Appel $\mathrm{H}$, Maier R, Bleil J, et al. In situ analysis of interleukin-23 and interleukin-12-positive cells in the spine of patients with ankylosing spondylitis. Arthritis Rheum 2013; 65: 1522-1529.

25. Paramarta JE, De Rycke L, Heijda TF, et al. Efficacy and safety of adalimumab for the treatment of peripheral arthritis in 
spondyloarthritis patients without ankylosing spondylitis or psoriatic arthritis. Ann Rheu Dis 2013; 72: 1793-1799.

26. Finzel $S$, Kraus $S$, Schmidt $S$, et al. Bone anabolic changes progress in psoriatic arthritis patients despite treatment with methotrexate or tumour necrosis factor inhibitors. Ann Rheum Dis 2013; 72: 1176-1181.

27. Hreggvidsdottir HS, Noordenbos T, Baeten DL. Inflammatory pathways in spondyloarthritis. Mol Immunol 2014; 57: 28-37.

28. Andersen T, Rasmussen TH, Hvid M, et al. Increased plasma levels of IL-21 and IL-23 in spondyloarthritis are not associated with clinical and MRI findings. Rheumatol Int 2012; 32: 387-393.

29. Bowness P, Ridley A, Shaw J, et al. Th17 cell epressing KIR3DL2 and responsive to HLA-B27 homodimers are increased in ankylosing spondylitis. J Immunol 2011; 186: 2672-2680.

30. Kenna TJ, Davidson SI, Duan R, et al. Enrichment of circulating interleukin-17-secreting interleukin-23-receptor positive $\gamma / \delta$ T cells in patients with active ankylosing spondylitis. Arthritis Rheum 2012; 64: 1420-1429.

31. Zhang L, Li Y, Qi L, et al. Increased frequencies of Th22 cells as well as Th17 cells in the peripheral blood of patients with ankylosing spondylitis and rheumatoid arthritis. PloS ONE 2012; 7: e31000

32. Kontny E. Nowe aspekty patogenezy spondyloartropatii zapalnych. Część II - czynniki środowiskowe, zaburzenia mikrobiomu, objawy pozastawowe. Reumatologia 2014; 52: 172-180.

33. Lories RJ, Luyten FP, de Vlam K. Progress in spondyloarthritis. Mechanisms of new bone formation in spondyloarthritis. Arthritis Res Ther 2009; 11: 221.

34. Komori T. Functions of the osteocyte network in the regulation of bone mass. Cell Tissue Res 2013; 352: 191-198.

35. Braun J, Bollow M, Neure L, et al. Use of immunohistologic and in situ hybridization techniques in the examination of sacroiliac joint biopsy specimens from patients with ankylosing spondylitis. Arthritis Rheum 1995; 38: 499-505.

36. Appel H, Ruiz-Heiland G, Listing J, et a. Altered skeletal expression of sclerostin and its link to radiographic progression in ankylosing spondylitis. Arthritis Rheum 2009; 60: 3257-3262.

37. Lories RJ, Derese I, Ceuppens JL, et al. Bone morphogenetic proteins 2 and 6 , expressed in arthritic synovium, are regulated by proinflammatory cytokines and differentially modulate fibroblast-like synoviocyte apoptosis. Arthritis Rheum 2003; 48: 807-818.

38. McGonagle D, Wakefield RJ, Tan AL, et al. Distinct topography of erosion and new bone formation in Achilles tendon enthesitis. Arthritis Rheum 2008; 58: 2694-2699.

39. Bleil J, Maier R, Hempfing A, et al. Histomorphological and histomorphometric characteristics of zygapophyseal joint remodeling in ankylosing spondylitis. Arthritis Rheum 2014; 66 1745-1754.

40. Braem K, Lories RJ. Insight into the pathophysiology of ankylosing spondylitis: contributions from animal models. Joint Bone Spine 2012; 79: 243-248.

41. Carter S, Braem K, Lories RJ. The role of bone morphogenic proteins in ankylosing spondylitis. Ther Adv Musculoskel Dis 2012: 4: 293-299.

42. Santos A, Bakker AD, Willems HM, et al. Mechanical loading stimulates BMP7, but not BMP2, production by osteocytes. Calcif Tissue Int 2011; 89: 318-326.
43. Bonewald LF, Johnson ML. Osteocytes, mechanosensing and Wnt signaling. Bone 2008; 42: 606-615.

44. Jacques P, Lambrecht $S$, Verheugen E, et al. Proof of concept: enthesitis and new bone formation in spondyloarthritis are driven by mechanical strain and stromal cells. Ann Rheum Dis 2014; 73: 437-445.

45. Chiowchanwisawakit P, Lambert RGW, Conner-Spady B, et al. Focal fat lesions at vertebral corners on magnetic resonance imaging predict the development of new syndesmophytes in ankylosing spondylitis. Arthritis Rheum 2011; 63: 2215-2225.

46. Baraliakos X, Heldmann F, Callhoff J, et al. Which spinal lesions are associated with new bone formation in patients with ankylosing spondylitis treated with anti-TNF agents? - a longterm observational study using magnetic resonance imaging and conventional radiography. Ann Rheum Dis 2013; doi: 10.1136/annrheumdis-2013-203425.

47. van Tubergen A, Ramiro S, van der Heijde D, et al. Development of new syndesmophytes and bridges in ankylosing spondylitis and their predictors: a longitudinal study. Ann Rheum Dis 2012; 71: 518-523.

48. Poddubnyy D, Haibel $\mathrm{H}$, Listing J, et al. Baseline radiographic damage, elevated acute-phase reactant levels, and cigarette smoking status predict spinal radiographic progression in early axial spondyloarthritis. Arthritis Rheum 2012; 64: 1388-1398.

49. Heiland GR, Appel H, Poddubnyy D, et al. High level of functional dickkopf-1 predicts protection from syndesmophyte formation in patients with ankylosing spondylitis. Ann Rheum Dis 2012; 71: 572-574.

50. Pedersen SJ, Chiowchanwisawakit P, Lambert RG, et al. Resolution of inflammation following treatment of ankylosing spondylitis is associated with new bone formation. J Rheumatol 2011; 38: 1349-1354.

51. Maksymowych WP, Morency N, Conner-Spady B, et al. Suppression of inflammation and effects on new bone formation in ankylosing spondylitis: evidence for a window of opportunity in disease modification. Ann Rheum Dis 2013; 72: 23-28.

52. Maksymowych WP. Evidence in support of the validity of the TNF brake hypothesis. Ann Rheum Dis 2013; 72: e31.

53. Baraliakos X, Haibel H, Listing J, et al. Continuous long-term anti-TNF therapy does not lead to an increase in the rate of new bone formation over 8 years in patients with ankylosing spondylitis. Ann Rheum Dis 2014; 73: 710-715.

54. Braun J, Baraliakos X, Hermann KG, et al. The effect of two golimumab doses on radiographic progression in ankylosing spondylitis: results through 4 years of the GO-RAISE trial. Ann Rheum Dis 2014; 73: 1107-1113.

55. Haroon N, Inman RD, Leach TJ, et al. The impact of TNF-inhibitors on radiographic progression in ankylosing spondylitis. Arthritis Rheum 2013; 65: 2645-2654.

56. Baraliakos X, Braun J. Response to "Evidence in support of the validity of the TNF brake hypothesis" by Maksymowych. Ann Rheum Dis 2013; 72: e32.

57. Lories RJU, Derese I, De Bari C, et al. Evidence for uncoupling of inflammation and joint remodelling in a mouse model of spondyloarthritis. Arthritis Rheum 2007; 56: 489-497.

58. Poddubnyy D, Rudwaleit M, Haibel H, et al. Effect of non-steroidal anti-inflammatory drugs on radiographic spinal progression in patients with axial spondyloarthritis: results from 
the German Spondyloarthritis Inception Cohort. Ann Rheum Dis 2012; 71: 1616-1622.

59. Kroon F, Landewe R, Dougados M, et al. Continuous NSAID use reverts the effects of inflammation on radiographic progression in patients with ankylosing spondylitis. Ann Rheum Dis 2012; 71: 1623-1629. 